\title{
SPRAY TUTOR: COMPUTER BASED TRAINING FOR SPRAY DRIFT MANAGEMENT
}

\author{
P. BELL ${ }^{1}$, S.F. GOUS ${ }^{2}$, M. HASLETT ${ }^{2}$, L. LESTER ${ }^{2}$, \\ R. LEWTHWAITE ${ }^{3}$, J.F. MABER ${ }^{4}$, B. RICHARDSON ${ }^{2}$, W. SCHOU ${ }^{2}$ \\ and J.A. ZABKIEWICZ2 \\ ${ }^{1}$ Ucol, P.B. 110222, Palmerston North \\ ${ }^{2}$ Forest Research, P.B. 3020, Rotorua \\ ${ }^{3}$ UNITEC, P.B. 92025, Auckland \\ ${ }^{4}$ Lincoln Ventures Ltd, P.B. 3062, Hamilton \\ Corresponding author:jaz@forestresearch.co.nz
}

\begin{abstract}
Spray Tutor is an interactive CD based software package containing a comprehensive training programme intended to illustrate and train users (through the GROWSAFE ${ }^{\circledR}$ courses operated by the New Zealand Agrichemical Education Trust) in the causes and effects of spray drift. It reflects New Zealand industry codes of practice, regulatory requirements and performance guidelines for safe, effective and responsible agrichemical application. It has captured the expertise of a range of experts in aerial and ground based spray application. It is compiled in four parts, with information as to the causes of spray drift, what influences spray drift, drift minimisation and drift management. The first two sections are largely instructive, with extensive but brief explanations for all the relevant factors, influences and effects of spray drift. The last two parts are quite different in that they primarily use interactive simulations of the factors affecting drift. These include different application methods (hand held, ground and aerial) and different sectors, including arable and pastoral farming, forestry (land preparation, releasing and health) and horticulture (market gardening and orchards), as well as amenity and turf management.
\end{abstract}

\section{IMPROVED FOREST VEGETATION MANAGEMENT USING VMAN}

\author{
B. RICHARDSON, W. SCHOU, M.O. KIMBERLEY and S.F. GOUS \\ Forest Research, Private Bag 3020, Rotorua, New Zealand \\ Corresponding author: brian.richardson@forestresearch.co.nz.
}

\begin{abstract}
Minimisation of pesticide use in New Zealand's plantation forests is critical to meet green certification requirements and public expectations in relation to environmental impacts and human health effects. With an increasing number of companies seeking or achieving Forest Stewardship Council (FSC) certification, this issue is of critical importance to the New Zealand forestry industry. VMAN is a decision support system that can help to minimise herbicide rates on moist, fertile sites in the Central North Island. The system requires three steps: (i) definition of acceptable levels of weed competition through the application of resource competition models; (ii) using herbicide/weed dose-response models to define appropriate herbicide doses for achieving target control levels; and (iii) definition of practical limits for spray deposit variation using an aerial spraying simulation model. The biological and physical basis of each of these components is discussed using a combination of already published and new data. The potential for herbicide reduction is then illustrated using a case study. Finally, steps being taken to implement this system and its extension to a wider range of site types are outlined.
\end{abstract}

